\title{
Spontaneous Labor and Birth
}

National Cancer Institute

\section{Source}

National Cancer Institute. Spontaneous Labor and Birth. NCI Thesaurus. Code C114102.

Initiation of labor without the use of pharmacological and/or mechanical interventions, resulting in a non-operative vaginal birth. (reVITALize) 